\title{
CUI-UI REPRODUCTIVE SUCCESS FROM POTENTIAL EGG DEPOSITION TO LARVAL EMIGRATION
}

\author{
G. Gary Scoppettone ${ }^{1,2}$ and Peter H. Rissler ${ }^{1}$
}

\begin{abstract}
From 1985 to 2006, we tracked cui-ui, Chasmistes cujus, survival from potential egg deposition of migrating spawners to emigrating larvae. Tahoe sucker larvae emigrated to Pyramid Lake the same time as cui-ui larvae, but cui-ui was the predominant catostomid larvae we captured. Survival of cui-ui larvae ranged from $0.46 \%$ to $21.17 \%$, declining significantly with decreased flow and increased number of spawners $(P<0.01)$. Mean total length of emigrating larvae ranged from 11.5 to $12.6 \mathrm{~mm}$ and may have been affected by stream flow. Removal of impediments to upstream migrating cui-ui spawners, along with sufficient stream flows, may enhance early life-stage survival.
\end{abstract}

Resumen.-Desde 1985 hasta 2006, rastreamos la supervivencia de peces cui-ui, Chasmistes cujus, de una posible deposición de huevos de hembras migratorias a larvas emigrantes. Las larvas del pez Tahoe sucker emigraron al Lago Pirámide al mismo tiempo que las larvas cui-ui, pero las cui-cui fueron las larvas catostómidas predominantes que capturamos. La supervivencia de las larvas cui-ui varió de $0.46 \%$ a $21.17 \%$, y disminuyó significativamente con la reducción del caudal y con el aumento de la cantidad de hembras en desove $(P<0.01)$. La longitud promedio de las larvas emigrantes varió de 11.5 a $12.6 \mathrm{~mm}$ en longitud total y pueden haberse visto afectadas por el caudal de la corriente. La remoción de los obstáculos para la migración aguas arriba de peces hembras cui-ui, junto con la provisión de suficiente caudal de corriente pueden mejorar la supervivencia en etapas tempranas de la vida.

Reproductive success is an important metric in assessing population health and in understanding a species' life history strategy and population dynamics (Stearns 1992, Williams et al. 2001). Data needed to estimate reproductive success are, however, difficult to secure (Houde 2002), and consequently, efforts have focused on commercially valuable species (Houde 1997, Hyatt et al. 2005, Landaeta and Castro 2006). There is less information on early life-stage survival for nongame fishes, including federally listed species.

Cui-ui Chasmistes cujus, a nongame species endemic to Pyramid Lake, Nevada, was federally listed as endangered because the population declined dramatically as a result of reproductive cycle disruption (U.S. Department of the Interior 1973). Disruption of cui-ui reproduction began in the 20th century when largescale water diversion from the Truckee River, Pyramid Lake's only perennial tributary, resulted in lake elevation decline and formation of a shallow delta at the river mouth (La Rivers 1962). Cui-ui, which are river spawners, were unable to enter the Truckee River to spawn in many years, and when they did, eggs were often scoured due to an unstable river bottom
(Scoppettone et al. 1986). Cui-ui longevity allowed it to persist more than a decade with little to no recruitment (Scoppettone et al. 1986, 2000, Scoppettone 1988). In the mid1970s, anthropogenic changes in the lower Truckee River improved cui-ui spawner passage. In late winter to early spring, adult cui-ui migrate to the southern end of Pyramid Lake and await environmental cues triggering their river spawning migration. Cui-ui typically migrate en masse and spawn over gravel substrate, with females crudely burying their demersal eggs by moving gravel with the anal fin (Scoppettone et al. 1983, 1986, Scoppettone and Vinyard 1991). The resulting progeny emigrate to Pyramid Lake upon swim-up and primarily at night. In this paper, we estimated run size, egg deposition, and larval survival over a 20-year period to better understand cui-ui reproductive patterns.

\section{Methods}

\section{Description of Area}

Pyramid Lake lies within the confines of the Pyramid Lake Paiute Indian Reservation in west-central Nevada, at the western edge of the

${ }^{1}$ U.S. Geological Survey, Western Fisheries Research Center, Reno Field Station, 1340 Financial Blvd., Suite 161, Reno, NV 89502.

2E-mail: gary_scoppettone@usgs.gov 


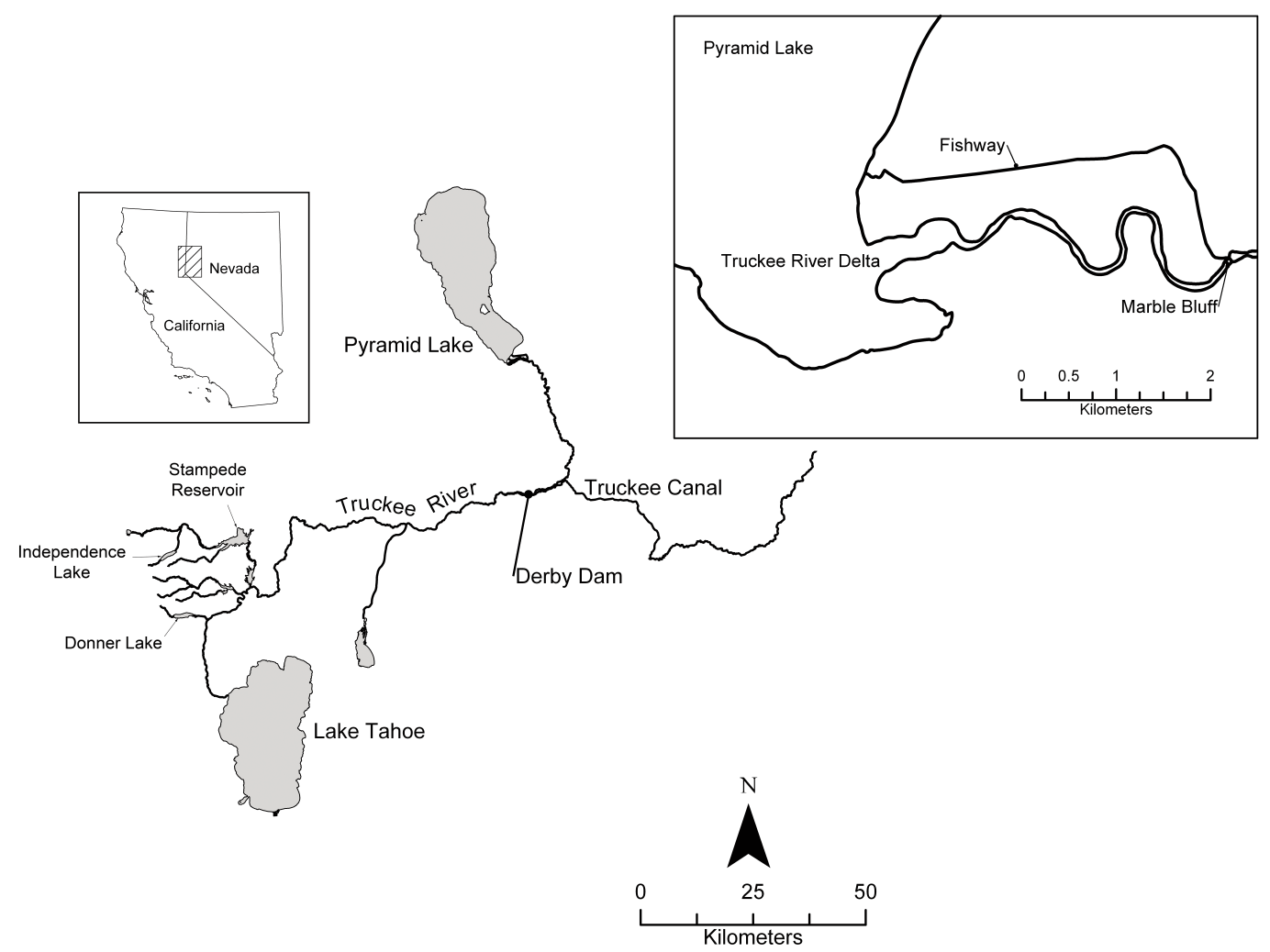

Fig. 1. Marble Bluff Dam and Marble Bluff Fishway in relation to Truckee River/Pyramid Lake. Insets, Truckee River/Pyramid Lake watershed, California and Nevada, and Marble Bluff Fishway in relation to Marble Bluff Dam.

Great Basin. It is a terminal lake with a surface area of approximately $785 \mathrm{~km}^{2}$. The mainstem Truckee River originates at Lake Tahoe, California, and flows $192 \mathrm{~km}$ before discharging into Pyramid Lake. Its primary water source is snowmelt and rain falling on the east side of the Sierra Nevada. The typical period from adult spawning migration to larval out-migration is April through June; during this study (1985-2006), lower Truckee River flows in these months ranged from about $1 \mathrm{~m}^{3} \cdot \mathrm{s}^{-1}$ to $75 \mathrm{~m}^{3} \cdot \mathrm{s}^{-1}$ (http://waterdata.usgs.gov/nwis). Stream flow is regulated, in part, by reservoir releases and water diversions. Since the late 1970s, water has been released from Stampede Reservoir to attract cui-ui spawners, facilitate their upstream river passage, and modify water temperature (U.S. Fish and Wildlife Service 1992). These flow releases have typically augmented natural flows. During 1987, 2003, and 2004, however, virtually the entire Truckee River flow entering Pyramid Lake originated from reservoir releases. Lake levels in these years were relatively high, and the delta was not an impediment to upstream migrants.

Marble Bluff Dam Complex was constructed to facilitate fish passage over the Truckee River delta. It consists of Marble Bluff Dam (MBD) and Marble Bluff Fishway (MBF); the MBF serves as a 5-km-long canal bypass around the Truckee River delta (Fig. 1). Upstream of Pyramid Lake, MBD prevents erosion associated with declining lake elevations, and it diverts water into the MBF (Glancy et al. 1972). When lake elevation is below $1170 \mathrm{~m}$, cui-ui access the river via the MBF, which flows at about $1.1 \mathrm{~m}^{3} \cdot \mathrm{sec}^{-1}$ and has 4 ice-harbor-type ladders along its course. There is a fish-handling building where fish are monitored, captured, and transported upstream of MBD. When lake elevation is $\geq 1170 \mathrm{~m}$, cui-ui migrate up the Truckee River, and they are trapped at the base of MBD, transported above the dam, measured, sexed, and released. From 1997 to the end of this study in 2006, the surface elevation of Pyramid Lake was sufficiently high 
that the $\mathrm{MBF}$ was closed, and cui-ui were trapped at the base of MBD.

Upstream of MBD there are several diversion dams that may impede the migration of spawners. Numana Dam, approximately $12 \mathrm{~km}$ upstream of MBD, diverts water to agricultural land on the Pyramid Lake Paiute Indian Reservation. The dam has a fish ladder, but its efficacy in passing cui-ui is untested. Beginning approximately $20 \mathrm{~km}$ upstream of Numana Dam, there are 3 rock diversion dams with unknown effects on migrating cui-ui, and Derby Dam (the largest diversion dam along the mainstem Truckee River) is approximately 40 $\mathrm{km}$ upstream of Numana. It is believed most cui-ui spawned downstream from Derby Dam, even prior to its completion in 1906 (La Rivers 1962), though they historically were collected at its base (Snyder 1918).

\section{Potential Egg Deposition}

We estimated the egg deposition potential for cui-ui females that passed upstream of MBD from 1985 to 2006 . There were spawning migrations in 15 of these 22 years. Cui-ui either did not migrate or there were too few females $(<100)$ to warrant monitoring during the remaining 7 years. To estimate total egg deposition, we used spawner counts, sex ratios, and mean size of females passed upstream of MBD (unpublished file data). Since only a fraction of cui-ui were measured and sexed during the run, we estimated total potential egg deposition for a given year as the product of the mean fecundity of measured females and the estimated number of females, based on sex ratios, passed upstream of MBD. The fecundity-size relationship was calculated by Scoppettone et al. (2000). These authors used 2 different regression equations to estimate fecundity: high fecundity following a year of no cui-ui spawning $(y=3.51 x-4.66)$ and low fecundity following a spawning year $(y=$ $3.07 x-3.51$ ), where $x=\log _{10}$ fork length of females captured at MBD and $y=\log _{10}$ estimated fecundity.

\section{Larvae Netting and Identification}

Because of the tremendous number of emigrating catostomid larvae, we found it practical to fish only 2 nets and often only for brief intervals. Nets were fished $30 \mathrm{~m}$ downstream from MBD and were $2.4 \mathrm{~m}$ long with a $50-\mathrm{cm}$ diameter mouth. They had a removable PVC cylinder (larvae receptacle) $20 \mathrm{~cm}$ deep and $8.5 \mathrm{~cm}$ wide at the cod end. The net mesh was 800 microns, and the cylinder had 500-micronmesh fiberglass along its length. Nets were fitted with a General Oceanic Digital Flow Meter and a harness for attachment to a cable extending across the river. The cable and attached nets were moved to and from fishing sites using a pulley system. One fishing site was near the center of the river, 15-20 $\mathrm{m}$ from the bank, and the other was $3-10 \mathrm{~m}$ from the bank. There were up to 60 exposed baffles equally spaced horizontally and vertically, projecting from the face of MBD. They serve to dissipate energy of the falling water and are assumed to mix larvae throughout the water column, creating the possibility for a single net to capture a representative sample of emigrating larvae passing over the dam (Fig. 2). To test this assumption, we conducted a paired $t$ test to determine if there was a difference in annual catches between nets. In 1985, 1986, and 1987, contents from the 2 nets were mixed and were not used in the test.

Throughout the period of larvae emigration, which ranges from mid-April through the end of July, drift nets were fished Monday, Wednesday, and Friday (beginning near dusk) for 5-20 min at hourly intervals over 4-6 h. The counter number on the digital flow meter was recorded prior to net setting. Immediately after nets were pulled, contents from each of the larvae receptacles were placed in separate 12 -L buckets, and the ending count of the digital flow meter was recorded. Captured catostomids were enumerated, and up to 50 randomly selected larvae were placed in a vial of $10 \%$ formalin for later species identification. Each vial contained a tag with date and time of capture along with the identifying number of the net.

We conducted diel sampling 1-3 times per season for a total of 24 episodes to determine daily emigration pattern of cui-ui larvae. We followed the same procedures as in our seasonal sampling, but over a 24 -h period, collecting a sample once every hour. Preserved catostomids were identified to species using a binocular dissecting scope and a key for catostomid larvae of the Truckee River Basin (Snyder 1983). Number of larvae was counted for each net and each sample hour. From 1994 to 2006, a subsample of at least 10 cui-ui larvae were randomly selected from each vial and 


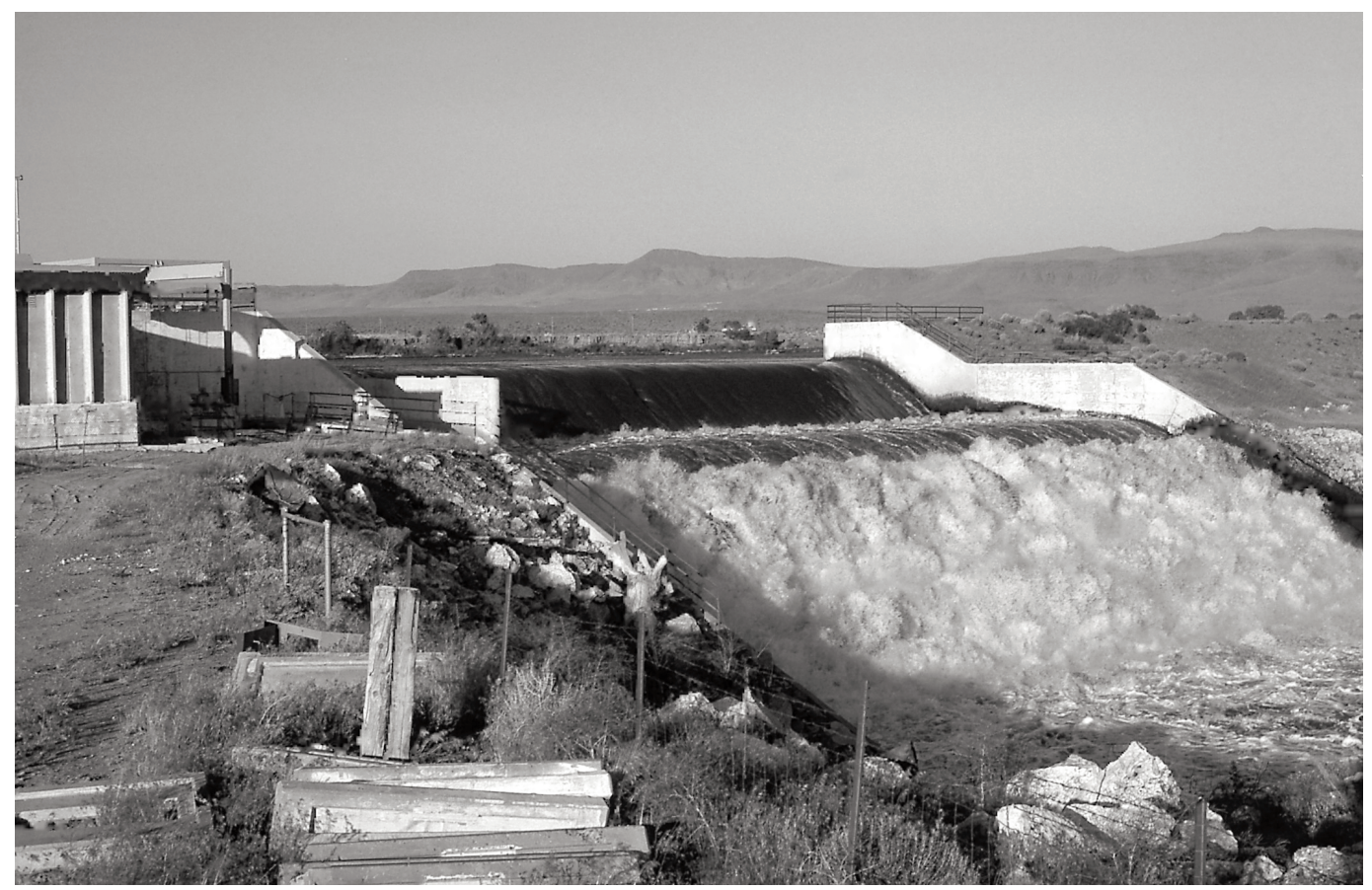

Fig. 2. Marble Bluff Dam showing baffles at the dam face.

measured to the nearest $0.01 \mathrm{~mm}$ (total length). The online National Water Information System of the U.S. Geological Survey (http://waterdata .usgs.gov/nwis) was used to track daily river flow at the Nixon gaging station, $2 \mathrm{~km}$ upstream of the larvae sampling site.

\section{Larvae Estimates}

We estimated number of cui-ui larvae emigrating past MBD for a given spawning year by first using the General Oceanic Digital Flow Meter to calculate the volume of water passed through each net for each 5-20 min fishing period and then counting the catostomid larvae in each net sample. In the laboratory, we determined the relative proportion of cui-ui to Tahoe sucker Catostomus tahoensis for each net set, and the number of cui-ui larvae captured was extrapolated to one hour. We then estimated number of cui-ui larvae $\cdot \mathrm{m}^{-3}$ passing over MBD during a 24-hour period for each Monday, Wednesday, and Friday of sampling. We used a linear regression equation with the number of cui-ui larvae $\cdot \mathrm{m}^{-3}$ captured over each of 24 diel episodes as the dependent variable, and the average number of cui-ui larvae $\cdot \mathrm{m}^{-3}$ for a given $4-6$-h sampling event as the independent variable. The estimated number of cui-ui larvae that passed $\mathrm{MBD}$ on a given day was the product of the number of larvae $\cdot \mathrm{m}^{-3}$ and total $\mathrm{m}^{3}$ that fell over MBD that day.

We estimated larvae numbers for those days sampled and then extrapolated larvae numbers for the season (estimated number of larvae for sampling days * number of days during emigration/number of sampling days). We typically sampled $29 \%-44 \%$ of the days in a given season. We feel this was a representative sample of larvae migration in a season.

\section{Survival}

In this paper, we define larval survival as the quotient of the estimated number of larvae produced in a given year divided by potential number of eggs deposited for that year (Pepin 2002). Regression analysis was used to determine if there was a relationship between survival of each of the sample years and magnitude of stream flow and density (number of male and female spawners passed upstream of MBD). To adjust for nonnormality and heterozygosity, survival was arcsine transformed, and density and flow were converted to a natural-log 
TABLE 1. Number of females (F) and males (M) passed upstream of Marble Bluff Dam, female mean length (mm), mean fecundity, expected number of eggs deposited, estimated number of larvae captured, and estimated egg-to-larvae survival over a 22 -year sampling period.

\begin{tabular}{|c|c|c|c|c|c|c|c|c|}
\hline \multirow[b]{2}{*}{ Year } & \multicolumn{2}{|c|}{ Number Passed } & \multirow{2}{*}{$\frac{\text { Mean FL }}{\mathrm{F}}$} & \multirow{2}{*}{$\begin{array}{c}\text { Mean } \\
\text { fecundity }\end{array}$} & \multirow{2}{*}{$\begin{array}{c}\text { Egg } \\
\text { estimate } \\
\times 10^{8}\end{array}$} & \multirow{2}{*}{$\begin{array}{l}\text { Larvae } \\
\text { estimate } \\
\times 10^{6}\end{array}$} & \multirow[b]{2}{*}{$\mathrm{SD} \times 10^{6}$} & \multirow{2}{*}{$\begin{array}{c}\text { Larval } \\
\text { survival } \\
(\%)\end{array}$} \\
\hline & $\mathrm{F}$ & M & & & & & & \\
\hline 1985 & 5945 & 3384 & 568 & 87,566 & 5.2 & 68.1 & - & $13.09 \%$ \\
\hline 1986 & 19,409 & 16,094 & 567 & 87,093 & 16.9 & 315.2 & - & $18.65 \%$ \\
\hline 1987 & 3220 & 2074 & 572 & 89,475 & 2.9 & 4.8 & - & $1.67 \%$ \\
\hline 1988 & - & - & - & - & - & - & - & - \\
\hline 1989 & 19 & 52 & - & - & - & - & - & - \\
\hline 1990 & - & 一 & - & - & - & - & - & - \\
\hline 1991 & - & - & - & - & - & - & - & - \\
\hline 1992 & - & - & - & - & - & - & - & - \\
\hline 1993 & 4842 & 14,151 & 528 & 72,159 & 3.5 & 38.6 & 0.9 & $11.05 \%$ \\
\hline 1994 & 22,597 & 43,754 & 542 & 75,822 & 17.1 & 142.8 & 15.3 & $8.34 \%$ \\
\hline 1995 & 37,777 & 61,316 & 542 & 75,822 & 28.6 & 606.4 & 65.4 & $21.17 \%$ \\
\hline 1996 & 84,771 & 86,897 & 542 & 75,822 & 64.3 & 653.8 & 53.4 & $10.17 \%$ \\
\hline 1997 & 157,975 & 149,011 & 540 & 74,965 & 118.4 & 1164.5 & 32.1 & $9.83 \%$ \\
\hline 1998 & 273,268 & 218,715 & 541 & 75,393 & 206.0 & 144.1 & 5.9 & $0.70 \%$ \\
\hline 1999 & 298,214 & 284,930 & 549 & 78,872 & 235.2 & 302.5 & 16.6 & $1.29 \%$ \\
\hline 2000 & 83,958 & 98,185 & 568 & 87,566 & 73.5 & 171.4 & 1.5 & $2.33 \%$ \\
\hline 2001 & - & - & - & - & - & - & - & - \\
\hline 2002 & 17,940 & 20,149 & 565 & 86,152 & 15.5 & 73.1 & 0.2 & $4.73 \%$ \\
\hline 2003 & 76,807 & 82,695 & 546 & 77,555 & 59.6 & 138.7 & 9.8 & $2.33 \%$ \\
\hline 2004 & 69 & 100 & - & - & - & - & - & - \\
\hline 2005 & 582,787 & 772,879 & 532 & 71,604 & 417.3 & 191.8 & 6.6 & $0.46 \%$ \\
\hline 2006 & 478,649 & 473,972 & 534 & 72,435 & 346.7 & 160.0 & 42.9 & $0.46 \%$ \\
\hline
\end{tabular}

value. Stream flow was measured at the Nixon gage and was the average for April, May, and June for a given year (http://waterdata.usgs .gov/nwis). Multiple regression models were ranked according to their $\mathrm{AIC}_{c}$ value (Burnham and Anderson 2002, Motulsky and Christopoulos 2004).

\section{RESULTS}

Potential Egg Deposition Larvae Estimates

There was a broad range in potential number of eggs deposited in the 15 years we studied. Estimated egg release varied from 2.9 $\times 10^{8}$ eggs in 1987 to $417.3 \times 10^{8}$ eggs in 2005 (Table 1).

Cui-ui were the predominant catostomid larvae captured in our 15 years of sampling (Fig. 3). The relative abundance of Tahoe sucker larvae declined over the course of the study. Annual cui-ui larvae net catches for the 2 nets fished were generally similar over the 12 years of comparison. There was no significant difference $(\mathrm{df}=11, t=-0.33, P=0.75)$ in numbers of cui-ui larvae captured between the 2 nets.

There was a strong positive relationship between the number of cui-ui larvae $\cdot \mathrm{m}^{-3}$ for each seasonal 4-6-h netting event and the number of cui-ui larvae $\cdot \mathrm{m}^{-3}$ for the $24-\mathrm{h}$ periods (Table 2). Estimated number of cui-ui larvae emigrating past MBD ranged from 4.8 million in 1987 to 1.2 billion in 1997 (Table 2). The SD between the 2 nets from 1993 through 2006 ranged from $0.2 \times 10^{6}$ in 2002 to $65.4 \times$ $10^{6}$ in 1995. Annual mean larval lengths ranged from $11.5 \mathrm{~mm}$ TL in 2003 to $12.7 \mathrm{~mm}$ TL in 1999, and the mean for all 12 years was $12.4 \mathrm{~mm}$. There was a trend toward increasing larvae length with increasing stream flow, but this relationship was not significant $(R=0.49$, $\mathrm{df}=9, P=0.070)$.

\section{Survival}

Survival from potential egg deposition to emigration to MBD ranged from $0.5 \%$ in 2005 and 2006 to $21.2 \%$ in 1995 (Table 1). The regression model with the lowest $\mathrm{AIC}_{c}$ score (104.9) and highest Akaike weight (0.685) contained both flow and density $\left(\mathrm{R}^{2}=0.5, P=\right.$ 0.01; Table 3).

\section{Discussion}

There was a broad range in survival rate from potential egg deposition of migrating 


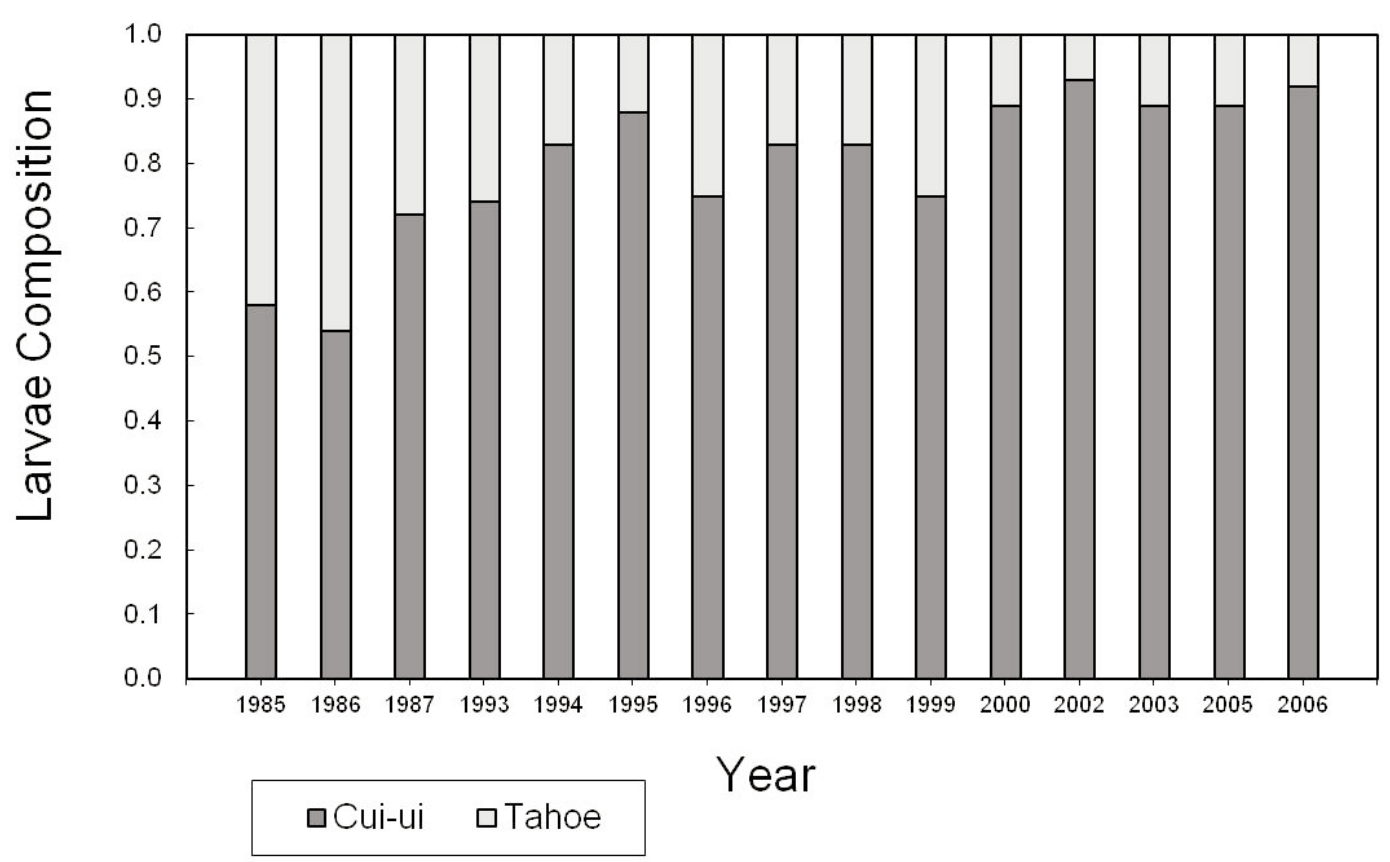

Fig. 3. Relative percent of cui-ui and Tahoe sucker larvae captured per year in 15 sampling years over a period of 22 years.

TABLE 2. Linear regression between 4- and 6-h sample periods and 24-h diels with $\mathrm{R}^{2}$ and probability $(P)$.

\begin{tabular}{lcccrc}
\hline Years & Sample time & $\mathrm{R}^{2}$ & $\mathrm{df}$ & \multicolumn{1}{c}{$F$} & $P$ \\
\hline 1993 & $19: 00-00: 00$ & 0.97 & 1,22 & 673 & $<0.001$ \\
1993 & $19: 00-01: 00$ & 0.98 & 1,22 & 1240 & $<0.001$ \\
$1994,1995,1996$ & $20: 00-23: 00$ & 0.91 & 1,22 & 223 & $<0.001$ \\
2005 & $20: 00-02: 00$ & 0.98 & 1,22 & 1192 & $<0.001$ \\
$1985,1986,1996,1997,1998,1999$ & $21: 00-01: 00$ & 0.97 & 1,22 & 672 & $<0.001$ \\
2002,2003 & $22: 00-01: 00$ & 0.98 & 1,22 & 1077 & $<0.001$ \\
\hline
\end{tabular}

TABLE 3. Values of the Akaike's information criterion $\left(\mathrm{AIC}_{c}\right)$ used to select the best model from 4 candidate models of cui-ui larval survival in the Truckee River, Nevada, 1985-2006. Density is the number of adult cui-ui passed upstream of MBD in a given year. Flow is the average daily flow $\left(\mathrm{m}^{3} \cdot \mathrm{s}^{-1}\right)$ for April, May, and June of each year measured at the Nixon gaging station. The best model (lowest $\mathrm{AIC}_{c}$ value) is presented first; $\triangle \mathrm{AIC}_{c}$ is the difference between $\mathrm{AIC}_{c}$ values of the individual models and that of the best model. Akaike weights $(\omega)$ provide a measure of each model's relative weight or likelihood of being the best model in the data set given. $\mathrm{K}$ is the number of parameters in the model.

\begin{tabular}{lcccccccc}
\hline Model & $\mathrm{R}^{2}$ & $\mathrm{df}$ & $F$ & $P$ & $\mathrm{AIC}_{c}$ & $\Delta \mathrm{AIC}_{c}$ & $\omega$ & $\mathrm{K}$ \\
\hline Density + Flow + Constant & 0.514 & 2,12 & 6.351 & 0.013 & 104.894 & 0.000 & 0.685 & 3 \\
Density + Constant & 0.254 & 1,13 & 4.433 & 0.055 & 107.504 & 2.610 & 0.186 & 2 \\
Constant & - & - & - & - & 108.724 & 3.830 & 0.101 & 1 \\
Flow + Constant & 0.042 & 1,13 & 0.566 & 0.465 & 111.266 & 6.372 & 0.028 & 2 \\
\hline
\end{tabular}

spawners to their emigrating progeny. Influencing this range was magnitude of stream flow and number of spawners released upstream of MBD. Survival tended to be greater with higher flows, and we suspect this was due to cooler water temperatures (Scoppettone et al. 1993). Also, high flows can facilitate egg oxygenation and metabolic waste removal, leading to greater survival (Heard 1991, Greig et al. 2006). Reproductive success as related to water quality may also have a density-dependent influence (Elliott 1990). We suspect that restriction of spawning habitat caused by dams leads to overcrowding in spawning sites, 
since lowest survival occurred in years with the greatest number of spawners. As eggs pile on top of each other, there may be insufficient oxygen to accommodate all eggs or later spawners may physically disturb incubating eggs (Pepin 2002).

Other studies tracking catostomid larvae emigration to lake environments (Geen et al. 1966, Modde and Muirhead 1994, Cooperman and Markle 2003) typically have not estimated survival. However, Ellsworth et al. (2010) determined that June suckers, Chasmistes liorus, experienced recruitment failure in years of low flow. The MBD Complex allowed us to estimate reproductive potential from the number and mean size of females passed upstream. The estimates are not adjusted for spawner mortality (Scoppettone et al. 2006) or residual egg retention; consequently, our survival estimates from egg deposition to emigrating larvae are likely conservative. The MBD Complex also provided the opportunity to estimate the number of emigrating cui-ui larvae.

This study gives survival estimates from potential egg deposition of spawner to emigrating larvae for an endangered catostomid over a 21-year period. Comparable early lifestage data on population survival are rare because there is typically not the opportunity to sample larvae for most fish populations and systems (Houde 2002). These results may be helpful in understanding the population dynamics of other long-lived western North American lake suckers and may enhance information on conditions affecting cui-ui population dynamics (Emlen et al. 1993). Our study suggests that increasing the amount of spawning habitat (currently restricted by inability of fish to move past dams) and increasing seasonal river flows would increase cui-ui survival from egg to emigrating larvae in this system.

\section{ACKNOWLEDGMENTS}

We give a special thanks to the Pyramid Lake Paiute Tribe for allowing us to work on their lake and for providing us assistance whenever needed. We also thank the U.S. Fish and Wildlife Service for funding this project. People assisting in field sampling included Melissa Grader, Bridget Nielsen, Stephanie Byers, Renee Anderson, Tracy Leavy, Kristin Swain, Mary Langsner, Edward Newberry, Mathew Jenkins, James Harvey, Sean Shea,
Stewart Reinbold, Matt Speth, Mathew Franz, Ryan McShane, Chris Mace, Tom Skiles, Travis Anderson, Antonio Salgado, Mark Fabes, Paul Guidici, Renee Thomson, and America Corp personnel. We thank Tom Strekal for his critical editorial review. Any use of trade names is for descriptive purposes only and does not imply endorsement by the U.S. Government.

\section{Literature Cited}

Burnham, K.P., AND D.R. Anderson. 2002. Model selection and multimodel inference: a practical information-theoretic approach. Springer Science, New York, NY.

Cooperman, M., and D.F. Markle. 2003. Rapid outmigration of Lost River and shortnose sucker larvae from in-river spawning beds to in-lake rearing grounds. Transactions of the American Fisheries Society 132:1138-1153.

ELLIOTT, J.M. 1990. Mechanisms responsible for population regulation in young migratory trout, Salmo trutta. III. The role of territorial behavior. Journal of Animal Ecology 59:803-818.

Ellsworth, C.M., M.C. BelK, And C.J. Keleher. 2010. Residence time and drift patterns of larval June sucker Chasmistes liorus in the lower Provo River as determined by otolith microstructure. Journal of Biology 77:526-537.

Emlen, J.M., T.A. Strekal, and C.C. Buchanan. 1993. Probabilistic projections for recovery of the endangered cui-ui. North American Journal of Fisheries Management 13:467-474.

Geen, G.H., T.G. Northcote, G.F. Hartman, and C.C. LINDSEY. 1966. Life histories of two species of catostomid fishes on Sixteen Mile Lake, British Columbia, with particular reference to inlet stream spawning. Journal of the Fisheries Board of Canada 23:1761-1788.

Glancy, P.A., A.S. Van DenBurgh, and S.M. Born. 1972 Runoff, erosion, and solutes in the lower Truckee River, Nevada, during 1969. Water Resources Bulletin 8:1157-1172.

Greig, S., D. Sear, and P. Carling. 2006. A field-based assessment of oxygen supply to incubating Atlantic salmon (Salmo salar). Hydrological Processes 21: 3087-3100.

HEARD, W.R. 1991. Life history of pink salmon (Oncorhynchus gorbuscha). Pages 121-230 in C. Groot and L. Margolis, editors, Pacific salmon life histories. Department of Fisheries and Oceans, Biological Sciences Branch, Pacific Biological Station, Nanaimo, British Columbia, Canada. University of British Columbia Press, Vancouver, British Columbia, Canada.

HoudE, E.D. 1997. Patterns and trends in larval-stage growth and mortality of teleost fish. Journal of Fish Biology 51:52-83.

2002. Mortality. Pages 64-87 in L.A. Fuiman and R.G. Werner, editors, Fishery science: the unique contributions of early life stages.

Hyatt, K.D., K.L. Mathias, D.J. McQueen, B. Mercer, P. Millian, and D.P. Rankin. 2005. Evaluation of hatchery versus wild sockeye salmon fry growth and 
survival in two British Columbia lakes. North American Journal of Fisheries Management 25:745-762.

Landaeta, M.F., AND L.R. Castro. 2006. Spawning and larval survival of the Chilean hake Merluccius gayi under later summer conditions in the Gulf of Aracuco, central Chile. Fisheries Research 77:115-121.

La Rivers, I. 1962. Fish and fisheries of Nevada. Nevada Game and Fish Commission, Carson City, NV.

Modde, T., AND N. Muirhead. 1994. Spawning chronology and larval emergence of June sucker (Chasmistes liorus). Great Basin Naturalist 54:366-370.

Motulsky, H., and A. Christopoulos. 2004. Fitting models to biological data using linear and nonlinear regression: a practical guide to curve fitting. Oxford University Press, New York, NY.

Pepin, P. 2002. Population analysis. Pages 112-142 in L.A Fuiman and R.G. Werner, editors, Fishery science: the unique contribution of early life stages. Blackwell Publishing, United Kingdom.

Scoppettone, G.G. 1988. Growth and longevity of the cui-ui and longevity of other catostomids and cyprinids in western North America. Transactions of the American Fisheries Society 117:301-307.

Scoppettone, G.G., M.E. Buettner, and P.H. Rissler. 1993. Effects of four fluctuating temperature regimes on cui-ui, Chasmistes cujus, survival from egg fertilization to swim-up, and size of larvae produced. Environmental Biology of Fishes 38:373-378.

Scoppettone, G.G., P.H. Rissler, and M.E. Buettner. 2000. Reproduction longevity and fecundity associated with nonannual spawning in cui-ui. Transactions of the American Fisheries Society 129:658-669.

Scoppettone, G.G., P.H. Rissler, D. Withers, and M.C. FABES. 2006. Fish tag recovery from the American White Pelican nesting colony on Anaho Island, Pyramid Lake, Nevada. Great Basin Birds 8:6-10.
SCOpPETtone, G.G., AND G. VinYARD. 1991. Life history and management of four endangered lacustrine suckers. Pages 359-377 in W.L. Minckley and J.E. Deacon, editors, Battle against extinction: native fish management in the American West. University of Arizona Press, Tucson, AZ.

Scoppettone, G.G., G.A. Wedemeyer, and M. ColeMAN. 1986. Life history and status of the endangered cui-ui of Pyramid Lake, Nevada. U.S. Fish and Wildlife Service Research 1:1-23.

Scoppettone, G.G., G.A. Wedemeyer, M. Coleman, AND H. BuRGE. 1983. Reproduction by the endangered cui-ui in the lower Truckee River. Transactions of the American Fisheries Society 112:788-793.

SNYDER, D.E. 1983. Identification of catostomid larvae in Pyramid Lake and the Truckee River, Nevada. Transactions of the American Fisheries Society 112: 333-348.

SNyder, J.O. 1918. The fishes of the Lahontan system of Nevada and north-eastern California. Bulletin of the U.S. Bureau of Fisheries 35:31-86.

StEarns, S.C. 1992. The evolution of life histories. Oxford University Press, New York, NY.

U.S. Department of the Interior. 1973. Threatened wildlife of the United States. U.S. Bureau of Sport Fisheries and Wildlife Resources, Publication 114, Washington, DC.

U.S. Fish and Wildlife Service. 1992. Cui-ui (Chasmistes cujus) Recovery Plan. 2nd revision. USFWS, Portland, OR.

Williams, B.K., J.D. Nichols, and M.J. CONROY. 2001. Analysis and management of animal populations. Academic Press, San Diego, CA.

Received 1 November 2011 Accepted 25 April 2012 